\title{
PENGUATAN KETAHANAN MASYARAKAT TERHADAP PANDEMI COVID-19 DENGAN PROGRAM KULIAH KERJA NYATA
}

\author{
Yuyun Estriyanto ${ }^{1}$ \\ ${ }^{1}$ Mechanical Engineering Education Dept., The Faculty of Teacher Training and Education \\ Sebelas Maret University Indonesia \\ Email: yuyun.e@staff.uns.ac.id
}

\begin{abstract}
The Covid-19 pandemic is a problem that is being faced by the majority countries in the world. Various efforts have been made to reduce the spread of the virus, one of which is community service activities carried out by students or commonly referred to as Community Service Program (CSP). This article reports the CSP activities in the context of handling the Covid-19 pandemic carried out by a group of students in their home areas during the period of limiting learning activities on campus. The activity uses the community education method which consists of the stages of initial observation, program preparation, program implementation, and evaluation. The results of the evaluation show that the CSP program contributes to increasing public understanding of the Coronavirus, awareness to implement health protocols, productive economic activities, and online learning activities during the enactment of extraordinary conditions.
\end{abstract}

Keywords: corona; covid-19; pandemic; CSP; public education.

\begin{abstract}
ABSTRAK
Pandemi Covid-19 merupakan masalah yang sedang dihadapi oleh mayoritas negara di dunia. Berbagai upaya dilakukan untuk mengurangi penyebaran virus tersebut, salah satunya dengan kegiatan pengabdian masyarakat yang dilakukan oleh mahasiswa atau biasa disebut dengan Kuliah Kerja Nyata (KKN). Artikel ini melaporkan kegiatan KKN dalam rangka penanganan pandemi Covid-19 yang dilakukan oleh sekelompok mahasiswa di daerah asalnya selama masa pembatasan aktifitas belajar dalam kampus. Kegiatan menggunakan metode pendidikan masyarakat yang terdiri dari tahapan observasi awal, persiapan program, pelaksanaan program, serta evaluasi. Hasil evaluasi menunjukkan bahwa program KKN berkontribusi meningkatkan pemahaman masyarakat akan virus Corona, kesadaran untuk melaksanakan protokol kesehatan, aktivitas ekonomi produktif, serta aktifitas pembelajaran dalam jaringan selama pemberlakuan kondisi luar biasa (KLB).
\end{abstract}

Kata kunci: corona; covid-19; pandemi; KKN; pendidikan masyarakat.

DOI: https://dx.doi.org/10.20961/dedikasi.v2i2.46541 


\section{PENDAHULUAN}

\section{Mengenal Pandemi Covid-19}

Awal tahun 2020, dunia diguncangkan dengan penyebaran virus Corona yang hampir melumpuhkan semua sendi kehidupan masyarakat. Virus ini menyebar pertama kali di Kota Wuhan, Propinsi Hubei, China pada Desember 2019, yaitu pada saat ada sejumlah kasus pneumonia dengan etiologi aneh yang kemudian diidentifikasi sebagai virus corona baru oleh Dr Jianghao Xu yang kemudian WHO secara resmi menamainya sebagai 2019-nCoV atau Covid-19 (Lu et al., 2020). Penyebaran virus ini, pada awalnya, diduga terjadi pada binatang karena penyebaran pertama terjadi di pusat grosir sea-food basah di Wuhan yang memperdagangkan kelelawar, ular, musang dan lain-lain (Kofi Ayittey et al., 2020). Proses penularan dari binatang kemanusia belum terkonfirmasi dengan jelas, akan tetapi, penularan yang sangat cepat dari manusia ke manusia lainnya telah terbukti secara luas (Shereen et al., 2020).

Virus corona tergolong dalam subfamili Orthocoronavirinae, famili Coronaviridae, ordo Nidovirales dimana virus ini memiliki empat genus yaitu virus corona -alpha, -beta, -gamma, dan-delta. Keempat genus diyakini memiliki asal mula zoonosis dan menginfeksi hewan dan manusia. Genus alfa dan beta berasal dari kelelawar sedangkan genus gamma dan delta berasal dari kumpulan gen unggas dan babi (Kofi Ayittey et al., 2020).

\section{Sikap Masyarakat terhadap Covid-19}

Sejauh ini, sikap yang ditunjukkan oleh masyarakat Indonesia terhadap Covid19 ini tak lepas dari tingkat pemahaman masing-masing individu. Menurut Yanti (2020), kemudahan untuk memperoleh informasi mampu meningkatkan pemahaman masyarakat, sehingga 59\% responden dengan pemahaman yang baik mampu menunjukkan sikap positif terhadap penanganan Covid-19 di Indonesia. Sedangkan $41 \%$ lainnya cenderung tidak mengindahkan himbauan pemerintah. Berbagai sikap negatif pun ditunjukkan oleh masyarakat, mulai dari tidak menggunakan masker saat berada di tempat umum, tidak menerapkan social distancing, hingga pergi berlibur ketika diterapkannya kebijakan bekerja dari rumah (work from home). Fenomena bias kognitif ini dapat terjadi karena rendahnya kemampuan literasi masyarakat, sehingga pemahaman atas merebaknya wabah Covid-19 ini tidak dapat dipahami secara maksimal (Buana, 2020).

\section{Pentingnya KKN Covid-19}

Sesuai dengan amanat Undang-Undang Republik Indonesia Nomor 20 Tahun 2003 tentang Sistem Pendidikan Nasional pada pasal 20 ayat 2 maka salah satu kewajiban perguruan tinggi adalah pengabdian masyarakat (Republik Indonesia, 2003). Wujud dari kegiatan pengabdian masyarakat tersebut salah satunya adalah 
Kuliah Kerja Nyata (KKN). Kuliah Kerja Nyata merupakan kegiatan pemberdayaan masyarakat dengan cara menerjunkan mahasiswa ke masyarakat. Mahasiswa bebas mencoba untuk memecahkan berbagai permasalahan di desa dimana ia ditempatkan. Sesuai dengan situasi dan kondisi masyarakat yang saat ini terdampak oleh pandemi Covid-19 maka program KKN dapat diarahkan untuk membantu masyarakat mengatasi pandemi ini. Sebagai kelompok masyarakat dengan jenjang pendidikan tinggi diharapkan mahasiswa dapat mengedukasi masyarakat untuk mencegah penularan Covid di daerah serta memberikan penguatan dalam menghadapi kondisi luar biasa (KLB) akibat pandemi Covid-19.

\section{TINJAUAN PUSTAKA}

\section{Penularan Covid-19}

Menurut WHO, infeksi pernafasan dapat ditularkan melalui tetesan dengan ukuran yang berbeda, yaitu, jika partikel tetesan berdiameter $>5-10 \mu \mathrm{m}$ maka disebut sebagai tetesan pernapasan sedangkan jika partikel berdiameter $<5 \mu \mathrm{m}$, maka disebut sebagai nuklei droplet (WHO, 2015). Menurut bukti saat ini, virus COVID-19 terutama ditularkan antar orang melalui tetesan pernapasan dan rute jejak-kontak (Liu et al., 2020). Hal itu didasari pada data pelacakan terhadap orangorang yang berkontak dekat dengan pasien yang pengidap Covid-19. Secara lengkap, WHO menjelaskan mekanisme penularan Covid-19 dapat terjadi dengan: (1) penularan tetesan, yaitu terjadi ketika seseorang berada dalam kontak dekat (dalam $1 \mathrm{~m}$ ) dengan orang yang memiliki gejala pernapasan (misalnya, batuk atau bersin) dan karena itu berisiko memiliki mukosa (mulut dan hidung) atau konjungtiva (mata) berpotensi terkena infeksi tetesan pernapasan; (2) kontak langsung, yaitu penularan terjadi melalui kontak langsung dengan orang yang terinfeksi atau kontak tidak langsung melalui permukaan benda yang pernah berkontak dengan penidap; dan (3) tranmisi udara, yaitu penularan akibat adanya virus dalam tetesan berukuran $<5 \mu \mathrm{m}$ dan tetap berada di udara dalam waktu yang lama sehingga dapat tertransmisikan ke orang lain pada jarak lebih dari $1 \mathrm{~m}$ (WHO, n.d.).

Di Indonesia, penyebaran Covid-19 masih terus berlangsung meskipun berbagai upaya telah dilakukan pemerintah untuk memutus rantai penyebaran virus tersebut. Sampai dengan Agustus, prosentase pasien meninggal tercatat mencapai 4,7 persen dan tingkat kesembuhan mencapai 63,2 persen. Pemerintah Indonesia menyedia situs pusat informasi penangan Covid-19 di https://covid19.go.id. Gambar 1 merupakan trend akumulasi nasional penyebaran Covid-19 di Indonesia hingga Agustus 2020 (Covid-19, n.d.). 


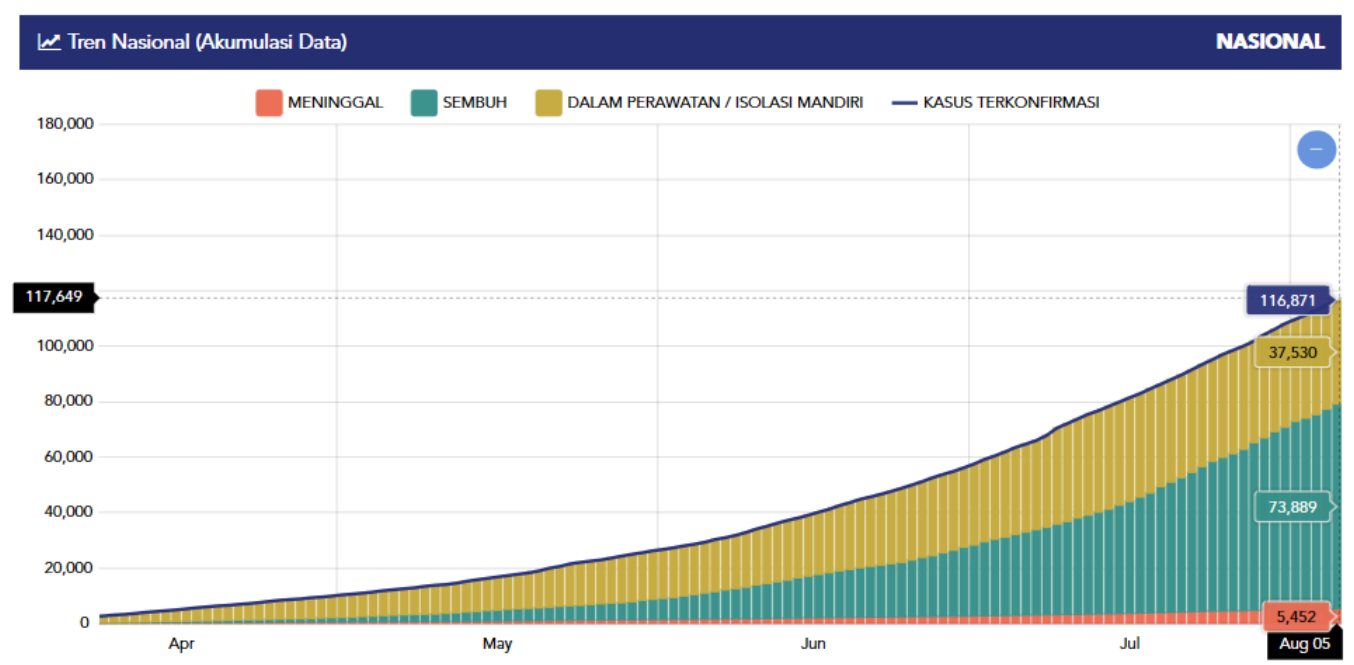

Gambar 1. Data Tren Akumulasi Nasional Penyebaran Covid-19 di Indonesia

\section{Dampak Sosial Ekonomi Akibat Pandemi Covid-19}

Peningkatan kasus Covid-19 di Indonesia berpengaruh besar terhadap kondisi sosial dan perekonomian nasional. Berbagai bentuk kebijakan pembatasan aktifitas masyarakat yang ditempuh untuk mencegah penyebaran COVID-19 otomatis menghambat dan menekan pertumbuhan ekonomi. Beberapa sektor yang terkena dampak akibat pandemic Covid-19 antara lain transportasi, pariwisata, perdagangan, pendidikan, kesehatan, dan yang paling serius adalah rumah tangga (Susilawati et al., 2020). Terhambatnya beberapa sektor diatas menyebabkan berkurangnya tenaga kerja yang dibutuhkan sehingga banyak perusahaan yang melakukan pemutusan hubungan kerja (PHK). Hal ini diprediksi akan menyebabkan tingkat kemiskinan di Indonesia semakin meningkat. Kemiskinan menjadi penyebab utama muculnya permasalahan ekonomi yang dibarengi dengan munculnya masalah sosial. Pertumbuhan ekonomi Indonesia pada tahun 2020, diperkirakan akan terkoreksi dari 5 persen menjadi hanya $1-4$ persen saja, sedangkan dampak terhadap jumlah kemiskinan yang paling ringan akan meningkat dari 9,2 persen pada September 2019 menjadi 9,7 persen pada akhir 2020 (Suryahadi et al., 2020).

\section{Kebijakan di Berbagai Negara untuk Menghentikan Penyebaran Covid-19}

Untuk menghadapi penyebaran Covid-19, negara-negara di seluruh dunia melakukan berbagai strategi untuk menghentikan penyebaran wabah ini. Chakraborty (2020) menyarankan adanya kolaborasi kemitraan yang luas semua pihak dan semua jenis profesi seperti ilmuwan, dokter, profesional medis, pekerja sosial, pembuat kebijakan, pemerintah, perusahaan farmasi, dan lembaga lembaga 
bantuan pendanaan agar sebuah bangsa dapat segera mengakhiri wabah dengan segera.

Irak, salah satu dari tujuh negara Arab yang terdampak Covid-19, mengambil langkah dengan memberlakukan lebih banyak pembatasan pada perjalanan dari negara-negara dengan wabah Covid-19 dan mencoba untuk mendapatkan bantuan dari masyarakat internasional untuk membantu melengkapi laboratorium khusus serta mengembangkan fasilitas karantina standar tinggi, menyediakan alat pelindung diri (APD), serta memberikan pelatihan medis bagi para profesional kesehatan (Mikhael \& Al-Jumaili, 2020). Arab Saudi mengambil tindakan pencegahan dengan cara larangan bepergian, menutup perbatasan, dan anjuran bekerja dari rumah dengan keyakinan bahwa tindakan ini adalah cara terbaik untuk melawan virus Covid-19 (Alshammari et al., 2020). Malaysia memberlakukan pembatasan gerak mulai 18 Maret 2020, menyebarkan tanda pagar \#tinggaldirumah, menggerakkan organisasi non-pemerintah untuk memproduksi peralatan perlindungan pribadi bagi para garis, penggalangan dana, pembangunan rumah sakit darurat, serta menambah kapasitas laboratorium uji untuk penanganan penyebaran Covid ini (Shah et al., 2020). Demikian halnya dengan Korea Selatan. Korea Selatan menggencarkan pelacakan kasus, menemukan orang terpapar, memberikan penugasan khusus bagi fasilitas perawat kesehatan, dan mengharuskan pengunjung rumah sakit dengan menggunakan masker. Usaha tersebut mampu menahan laju kasus baru per hari di sekitar 100 menjadi kurang dari 50 kasus setiap hari pada minggu kedua April 2020 (Kang et al., 2020).

\section{Upaya Penanganan Covid-19 di Indonesia}

Sejalan dengan usaha berbagai Negara untuk mengatasi penyebaran Covid, Indonesia pun juga memiliki grand desain untuk mengatasi pandemi ini. Berbagai kebijakan fiskal yang berpihak pada penanagan Covid telah beberapa kali dilakukan (Kemenkeu, n.d.). Berbagai upaya sebagaimana dilakukan oleh negara lain juga diberlakukan seperti pembatasan pergerakan masyarakat untuk mengurangi potensi penularan seperti pembatasan aktifitas tempat kerja dan sekolah, pembatasan transportasi, dan lain-lain. Berbagai upaya peningkatan kapasitas medis untuk penangan pasien juga dilakukan di semua daerah. Sosialisasi pencegahan penyebaran virus Covid-19 kepada masyarakat sangat diperlukan agar tidak menimbulkan sumber penularan atau klaster baru, termasuk penerapan kebijakan pemerintah dalam melakukan Pembatasan Sosial Berskala Besar (PSBB) dan karantina wilayah. Menurut Mona (2020), jaringan sosial tanpa peran isolasi memberi banyak peluang virus untuk menyebar, sedangkan jaringan sosial di mana banyak anggotanya melakukan isolasi membuat peluang penyebaran virus menjadi lebih rendah. Oleh karena itu, konsep isolasi dengan pembatasan pergerakan manusia menjadi sangat penting untuk menghambat penyebaran Covid ini. Kaur 
(2020) menemukan bahwa negara-negara yang menerapkan lockdown sejak awal secara ketat telah berhasil mengurangi tingkat penularan virus dengan baik.

Upaya mencegah penularan virus Covid-19 sekaligus melindungi diri sendiri dan orang lain dapat dilakukan dengan berbagai cara. Menurut Pedoman Pecegahan dan Pengendalian Coronavirus Disease (COVID-19) yang dterbitkan oleh Kementrian Kesehatan RI (Kemenkes, 2020), antara lain dapat dilakukan dengan cara membersihkan tangan secara teratur dengan sabun dan air mengalir, mencuci tangan selama 40-60 detik atau menggunakan handsanitizer minimal 20-30 detik untuk membunuh kuman yang menempel pada tangan, menggunakan alat pelindung diri seperti masker, face shield dan sarung tangan apabila keluar rumah atau berinteraksi dengan orang lain, dan setelah bepergian segera mandi dan membersihkan diri. Dianjurkan juga untuk menjaga jarak minimal 1 meter untuk menghindari terkena droplet dari orang yang bersin atau batuk dan membatasi diri pada saat kontak atau berinteraksi dengan orang lain yang tidak diketahui status kesehatannya. Selain itu, juga harus menjaga etika batuk dan bersin dengan cara menutup mulut dan hidung dengan siku terlipat atau menggunakan tisu. Hal lain yang perlu diperhatikan yaitu meningkatkan daya tahan tubuh dengan berolahraga, istirahat cukup dan konsumsi makanan dengan gizi seimbang.

\section{METODE}

Program KKN ini menyasar masyarakat terdampak pandemi yang berlokasi di Kabupaten Tegal dan Purbalingga. Program dilaksanakan selama bulan Mei-Juni 2020. Metode yang digunakan adalah pendidikan masyarakat yang dilaksanakan dalam empat tahapan yaitu observasi awal, persiapan program, pelaksanaan program, dan evaluasi. Observasi awal dilaksanakan untuk menganalisis masalah yang terjadi di lapangan. Observasi ini juga diperkuat dengan pra-survey menggunakan form daring yang disebarluaskan menggunakan group perpesanan instant Whatsapp. Persiapan program meliputi penyusunan program, penjadwalan, dan penyiapan perlengkapan untuk keberlangsungan program. Pelaksanaan kegiatan terdiri dari: (1) sosialisasi pencegahan penyebaran Covid-19; (2) sosialisasi anjuran physical/ sosial distancing dan stay at home; (3) pembuatan handsanitizer; (4) pembuatan dan penyemprotan disinfektan; (5) pembuatan masker kain; (6) pembuatan tempat cuci tangan; (7) sosialisasi kegiatan ekonomi produktif selama pandemic; (8) program ruang belajar daring dan pendampingan belajar kepada siswa; (9) edukasi penggunaan media pembelajaran online untuk guru setempat; dan (10) penerjunan relawan ratgas Covid-19 di daerah. Adapun tahapan evaluasi dilaksanakan dengan obervasional terhadap perubahan perilaku masyarakat serta dengan post-survey menggunakan kuisioner daring. 


\section{HASIL DAN PEMBAHASAN}

\section{Edukasi Masyarakat mengenai Pandemi Covid-19}

Kesadaran masyarakat merupakan kunci dalam menghentikan penyebaran Covid-19. Dasar pemikiran program KKN ini didasarkan pada teori Bloom yang dikutip pada Notoatmodjo (2003), bahwa kesadaran terbangun dari variabel pengetahuan, sikap, dan tindakan. Indikator tingkatan pengetahuan terdiri dari tahu, paham, apikasi, analisis, sintesis, dan evaluasi. Indikator tingkatan variabel sikap terdiri dari menerima, merespon, menghargai, dan tanggung jawab. Sedangkan indikator variabel tindakan terdiri dari persepsi, respon terpimpin, mekanisme, dan adopsi. Oleh karena itu untuk membangun kesadaran masyarakat untuk berperilaku tanggap pandemi maka harus dibangun pada ketiga aspek tersebut: pengetahuan, sikap, dan tindakan. Masyarakat akan memiliki kesadaran dan merealisasikan dalam tindakan tanggap Covid-19 jika telah memiliki pengetahuan dan sikap persepsional positif terhadap pandemi Covid-19. Oleh karena itu, program KKN mahasiswa ini diarahkan untuk melakukan edukasi masyarakat agar terbangun pengetahuan, sikap, dan realisasi tindakan seperti yang diharapkan.

Edukasi terhadap masyarakat perlu dilakukan karena masih banyak golongan masyarakat yang tidak acuh dan tidak memperhatikan protokol kesehatan dalam beraktivitas sehari-hari sebagaimana yang disampaikan oleh Yanti (2020). Hal tersebut juga ditemui di daerah KKN Covid-19 ini. Sesuai dengan teori di atas, artinya pengetahuan dan sikap persepsional sebagian masyarakat terhadap pandemi Covid-19 masih rendah. Seberapa pun jumlahnya, adanya anggota masyarakat pada level kesadaran ini akan membahayakan komunitas mengingat sifat penularan Covid-19 yang bisa terjadi baik dengan bersentuhan maupun tidak.

Program edukasi masyarakat dalam program KKN ini di antaranya: (1) edukasi tentang basic-knowledge virus Corona dan (2) edukasi protokol kesehatan untuk memutus penularan Covid-19. Salah satu contoh kegiatan edukasi basic-knowledge mengenai Covid-19 misalnya seperti yang dilakukan di Kelurahan Tunon. Kegiatan ini dilaksanakan setiap hari dari tanggal 27 Mei hingga 24 Juni, menyasar ibu-ibu PKK RT01 RW03 Kelurahan Tunon. Hal yang perlu disiapkan sebelum dilaksanakan program kerja ini yaitu merancang dan membuat materi mengenai virus Covid-19 berupa poster dan video. Kegiatan serupa juga dilakukan di desadesa yang lain. Poster dalam bentuk backdrop dipasang di lingkungan warga agar dapat dibaca oleh warga yang melintas, sedangkan untuk poster digital dan video disebarkan melalui media sosial kepada warga melalui group Whatsapp.

Dalam program KKN ini, mahasiswa juga memberikan edukasi pentingnya menggunakan masker selama beraktifitas. Edukasi dilaksanakan secara daring maupun luring. Banner dan poster ajakan untuk mematuhi protokol kesehatan yang dipasang pada berbagai lokasi strategis perkampungan, sedangkan poster digital disebar secara berkala kepada masyarakat melalui group Whatsapp. Bentuk edukasi 
masyarakat yang lain adalah penyulusan perilaku hidup bersih dan sehat (PHBS) sebagaimana yang dilakukan salah satu peserta KKN di lingkungan RT 01 RW 03 Kelurahan Tunon, Kecamatan Tegal Selatan, Kota Tegal. Pada kegiatan tersebut mahasiswa menstimulasi masyarakat dengan memberikan contoh sabun cuci tangan dan galon air agar masyarakat termotivasi menerapkannya. Stimulus yang disediakan mahasiswa tersebut hanya sebagai bahan edukasi, diharapkan masyarakat dapat mengadakannya untuk keperluannya sendiri secara mandiri. Sejumlah terbatas perangkat cuci tangan tersebut kemudian diletakkan di tempat umum, yaitu di musholla dan warung-warung sekitar agar memberi kemanfaatn dan efek edukasi yang luas. Selama kegiatan berlangsung, warga antusias untuk membantu dalam kegiatan pengadaan tempat cuci tangan ini. Beberapa hari setelah dilaksanakan program kerja ini, banyak warga termotivasi untuk membuat sendiri tempat cuci tangan untuk diletakkan di depan rumah masing-masing.

Untuk mengetahui keberhasilan program $\mathrm{KKN}$, peserta $\mathrm{KKN}$ membuat kuisioner daring untuk mengukur pengetahuan warga. Hasil kuisioner menunjukkan sebanyak $89 \%$ masyarakat paham dan sadar akan bahaya virus Covid-19. Adanya perubahan sikap masyarakat diamati dari perilaku keseharian masyarakat untuk menerapkan protokol kesehatan yang baik. Dari hasil pengamatan di dua puluh lokasi KKN, terlihat perubahan sedikit demi sedikit perilaku masyarakat yang mulai mematuhi protokol kesehatan, yaitu dengan menggunakan masker setiap keluar rumah, memakai handsanitizer, mencuci tangan sesuai dengan 7 langkah cuci tangan, serta menjaga jarak saat di luar rumah. Berdasarkan hasil pengamatan pada akhir program KKN, masyarakat semakin menunjukkan kesadaran dan kedisiplinan dalam penggunaan masker dari hari ke hari. Hal tersebut terlihat dari makin banyaknya masyarakat yang menggunakan masker ketika bepergian, beribadah ke masjid, dan ketika menghadiri acara sosial seperti arisan dan rapat warga.

Secara keseluruhan, kegiatan KKN untuk mengedukasi masyarakat mengenai penerapan protokol Covid-19 menunjukkan respon dan hasil yang positif dalam hal peningkatan kesadaran masyarakat. Namun, dari pengataman juga ditemukan fakta bahwa golongan anak-anak dan orang lanjut usia cukup sulit untuk diberi sosialisasi. Hal tersebut dikarenakan anak-anak masih ingin bebas bermain tanpa ada batasan. Untuk orang yang lanjut usia, tingkat pemikiran atau daya ingatnya yang sudah mulai menurun dan minim memperoleh informasi dari berbagai media digital sehingga menyebabkan edukasi ini kurang optimal.

\section{Penguatan Kemandirian Tanggap Pandemi Covid-19}

Dalam KKN ini, salah satu program yang juga dilaksanakan mahasiswa adalah peningkatan partifipasi mandiri penaganan Covid-19 dengan pemberdayaan berbagai sumber daya murah meriah yang ada di lingkungan sekitar. Mahasiswa KKN memberikan berbagai pelatihan baik secara luring dengan menerapkan 
protokol kesehatan muapun dengan daring dengan video-video tutorial yang disebarkan melalui group whatsapp dan media sosial lain seperti Facebook dan Instagram. Pelatihan tersebut antara lain bagaimana cara memanfaatkan bahanbahan alami seperti daun sirih dan jeruk nipis sebagai bahan pembuatan hand sanitizer dan bagaimana memanfaatkan kain perca untuk dibuat masker kain.

\section{Penguatan Aktivitas Perekonomian Masyarakat}

Dampak pandemi Covid-19 sangat terasa pada sektor perekonomian. Tidak hanya pelaku usaha besar yang merasakan kerugian, namun juga dialami oleh pelaku usaha skala kecil yang masuk kategori usaha mikro, kecil, dan menengah (UMKM). Kegiatan perekonomian di sektor pangan atau kuliner merupakan salah satu bidang yang terimbas di daerah KKN, terutama pedagang kaki lima (PKL) di daerah Kabupaten Tegal dan Purbalingga. Para PKL yang mengalami penurunan pembeli semenjak merebaknya virus Corona karena adanya PSBB yang menyebabkan berkurangnya aktifitas masyarakat di luar rumah. Konsumen umumnya merasa khawatir untuk membeli makanan di luar karena tidak ada jaminan makanan yang dibeli bersih dan higienis. Berdasarkan situasi tersebut, upaya yang dilakukan mahasiswa KKN adalah dengan mengedukasi untuk disiplin mencuci tangan dengan benar menggunakan sabun dan air mengalir bagi para PKL. Dengan demikian, diharapkan upaya pencegahan penularan Covid dapat terlaksana akan tetapi juga mengembalikan kepercayaan masyarakat untuk membeli dagangannya. Di sisi lain, mahasiswa KKN juga melaksanakan program dengan memberikan tips-tips kepada masyarakat seputar belanja aman saat pandemi, tips aman belanja di pasar tradisional, tips aman belanja di supermarket, dan tips aman menerima paket belanja online. Edukasi tersebut dilakukan dalam bentuk flyer digital yang di sebar melalui postingan Instagram dan Whatsapp. Hal ini dilakukan untuk menghilangkan rasa khawatir masyarakat untuk berbelanja di masa pandemi, yang diharapkan dapat meningkatkan geliat ekonomi di Indonesia.

Berkurangnya kegiatan perekonomian akibat PSBB mengakibatkan masyarakat yang terdampak mengalami penuruan daya beli, khususnya bagi pekerja informal. Mereka terdampak pada pekerjaannya, sedangkan pengeluaran keluarga justru bertambah untuk memenuhi kebutuhan yang tidak direncanakan sebelumnya seperti pembelian masker, disinfektan, vitamin, dan lain-lain. Untuk meminimalisir dampak perekonomian tersebut, relawan KKN mensosialisasikan pembuatan masker kain secara mandiri berupa tutorial video dan gambar (poster grafis) yang kemudian dibagikan pada media sosial group whatsapp warga setempat dengan harapan warga dapat menghemat biaya pengeluaran untuk kebutuhan pokok baru yang tidak direncanakan tersebut. Tidak hanya pembuatan masker, relawan juga membagikan tutorial pembuatan disifektan melalui kanal Youtube pribadi yang kemudian disosialisasikan ke group whatsapp warga agar warga dapat belajar secara mandiri. Dengan demikian, warga setempat dapat meningkatkan kegiatan 
ekonomi di rumah dengan menghemat pengeluaran atau membuat produk barang untuk kemudian dijual guna meningkatkan penghasilan.

\section{Penguatan Aktivitas Pendidikan Masyarakat}

Kondisi luar biasa akibat pandemi Covid-19 membuat sistem pendidikan di Indonesia harus berubah dari tatap muka luring menjadi daring. Program belajar dari rumah (learn from home) menjadi salah satu opsi yang dilakukan pemerintah untuk mengatasi masalah pendidikan pada saat KLB. Pelaksanaan pembelajaran secara daring memerlukan fasilitasi perangkat keras elektronik berupa laptop dan telpon pintar, paket data internet, dan juga keadaan sinyal operator jaringan di setiap lokasi. Pelaksanaan sekolah secara daring ini menemui banyak hambatan di masyarakat, antara lain: (1) tidak semua siswa mempunyai handphone; (2) sinyal operator jaringan yang tidak merata; (3) ketidakmampuan membiayai kuota internet; (4) kompetensi orang tua dalam mendampingi menggunakan perangkat teknologi informasi; dan (5) keterbatasan waktu orang tua karena harus membagi waktu dengan pekerjaan. Pengabdian masyarakat melalui KKN Covid-19 memberikan kontribusi kepada masyarakat Desa Banjarkerta khususnya di bidang pendidikan dalam bentuk bimbingan belajar luring untuk membimbing anak-anak dalam belajar dengan tetap menjaga protokol kesehatan. Para siswa antusias dengan kegiatan ini dan lebih memahami materi yang diberikan dibandingkan dengan sekedar pembelajaran daring.

Mahasiswa KKN juga membuat forum kreatif yang disebut dengan forum 'Matematika', yaitu pendampingan belajar dan konsultasi tugas gratis khusus materi matematika. Kegiatan dilakukan secara daring melalui Whatsapp dan Facebook dan dikolaborasikan dengan luring di desa Banjarsari. Hasil dari kegiatan bimbingan belajar ini, selain siswa-siswi menjadi lebih paham dengan materi pembelajaran, juga tersusun e-book soal dan pembahasan matematika SD-SMA \& SBMPTN untuk disebarluaskan secara gratis sehingga memudahkan siswa di daerah dalam belajar. Kegiatan bimbingan belajar tidak hanya dilakukan saat masa KKN saja, namun kegiatan juga berlangsung setelah KKN usai bahkan masih berlangsung hingga sekarang melalui forum Facebook.

Dalam program KKN ini, selain pendampingan belajar juga dilakukan web seminar atau seminar daring yang dilaksanakan dua kali melalui Google Meet dan live streaming Youtube. Seminar daring pertama dengan tema "Kehidupan Dunia Kampus" berfokus pada siswa-siswi SMA/K yang akan melanjutkan ke perguruan tinggi. Seminar daring kedua dengan tema "Peran Matematika di Era Covid 19" diikuti oleh pelajar dan masyarakat umum. Peserta yang mengikuti seminar sangat antusias dengan materi yang disampaikan, mereka merasa materi yang disampaikan sangat bermanfaat dan sangat membantu di saat masa pandemi seperti sekarang. Hal ini terlihat dari komentar peserta di kolom kometar Youtube dan di group Whatsapp peserta, bahkan setelah seminar selesai, banyak yang menginginkan 
kegiatan serupa diadakan kembali. Hal ini menunjukkan bahwa acara-acara yang diselenggarakan mahasiswa KKN memberikan manfaat bagi masyarakat, khususnya dalam bidang pendidikan.

\section{KESIMPULAN}

Pandemi Covid-19 merupakan masalah global yang berpengaruh pada seluruh sendi kehidupan sosial masyarakat. Saat ini, bagaimana masyarakat menyikapi pandemi sangat beragam. Hal ini kemungkinan disebabkan banyak aspek seperti tingkat pendidikan, umur, pergaulan, akses terhadap informasi dan lain-lain. Pembatasan aktifitas sosial masyarakat menimbulkan banyak permasalahan sosial ekonomi lain yang tidak bisa dihindari sehingga masyarakat membutuhkan pendampingan dan penguatan untuk melalui masa pandemi ini dengan baik. Program KKN Tanggap Covid-19 sebagaimana yang dilaporkan dalam artikel ini menunjukkan bahwa mahasiswa mampu memberikan andil positif bagi masyarakat di daerahnya dalam mengahadapi pandemi. Sebaliknya, masyarakat terlihat membutuhkan peran-peran aksi sosial sebagaimana yang dilakukan mahasiswa KKN untuk mengatasi berbagai masalah yang terjadi di masyarakat. Program KKN ini terbukti mampu meningkatkan: (1) pemahaman masyarakat tentang Covid-19; (2) kesadaran (awareness) untuk melaksanakan protokol kesehatan Covid-19; (3) aktivitas perekonomian produktif; dan (4) aktivitas pendidikan daring selama KLB.

\section{UCAPAN TERIMA KASIH}

Artikel ini merupakan artikel luaran kegiatan KKN Covid-19 UNS Tahun 2020. Ucapan terima kasih kepada Unit Pengelola KKN Universitas Sebelas Maret (UNS) yang telah menelenggarakan KKN Covid-19 ini dan seluruh anggota tim KKN Covid-19 Batch II UNS kelompok 83: Aprilia Ayuningtyas, Lubena Umaya, Galuh Budhi Anindita, Deni Setyaningsih, Lufi Indaryati, Rizka Yuniar, Eva Amalia Hanif, Hana Nur Adila, Luthfiatul Azizah Aini, Sulis Setyawati, Windhi Kurniasih, Neli Nurhayati, Dewi Nur Hikmah, Steffina Indri Hapsari, Alfiati Safira Salma, Nur Shofa Riyana, Mujadid Amar Rahman, Umi Rosidah, Yefta Widianto, dan Maulidya Dwi Anggini.

\section{DAFTAR PUSTAKA}

Alshammari, T. M., Altebainawi, A. F., \& Alenzi, K. A. (2020). Importance of early precautionary actions in avoiding the spread of COVID-19: Saudi Arabia as an Example. Saudi Pharmaceutical Journal, 28(7), 898-902. https://doi.org/10.1016/j.jsps.2020.05.005

Buana, D. R. (2020). Analisis Perilaku Masyarakat Indonesia dalam Menghadapi 
Pandemi Virus Corona (Covid-19) dan Kiat Menjaga Kesejahteraan Jiwa. SALAM: Jurnal Sosial Dan Budaya Syar-I, 7(3), 217-226. https://doi.org/10.15408/sjsbs.v7i3.15082

Chakraborty, C., Sharma, A. R., Sharma, G., Bhattacharya, M., Saha, R. P., \& Lee, S. S. (2020). Extensive Partnership, Collaboration, and Teamwork is Required to Stop the COVID-19 Outbreak. Archives of Medical Research. https://doi.org/10.1016/j.arcmed.2020.05.021

Covid-19, G. (n.d.). Peta Sebaran| Gugus Tugas Percepatan Penanganan COVID19. Retrieved August 6, 2020, from https://covid19.go.id/peta-sebaran

Hermawan, B., Bettiza, M., \& Hayaty, N. (2018). Menentukan tingkat kematangan buah pepaya dengan ekstraksi warna. Universitas Maritim Raja Ali Haji.

Kang, J. H., Jang, Y. Y., Kim, J. H., Han, S. H., Lee, K. R., Kim, M., \& Eom, J. S. (2020). South Korea's responses to stop the COVID-19 pandemic. American Journal of Infection Control, O(0). https://doi.org/10.1016/j.ajic.2020.06.003

Kaur, T., Sarkar, S., Chowdhury, S., Sinha, S. K., Jolly, M. K., \& Dutta, P. S. (2020). Anticipating the novel coronavirus disease (COVID-19) pandemic. MedRxiv, 2020.04.08.20057430. https://doi.org/10.1101/2020.04.08.20057430

Kemenkes. (2020). Pedoman Pencegahan dan Pengendalian CORONAVIRUS DISEASE (COVID-19) Revisi ke-5. Kementerian Kesehatan RI Pengarah. https://doi.org/10.33654/math.v4i0.299

Kemenkeu. (n.d.). Siaran Pers Menjaga Ekonomi Indonesia Terhadap Dampak Negatif Pandemik COVID-19. Retrieved August 6, 2020, from https://www.kemenkeu.go.id/publikasi/siaran-pers/siaran-pers-menjagaekonomi-indonesia-terhadap-dampak-negatif-pandemik-covid-19/

Kofi Ayittey, F., Dzuvor, C., Kormla Ayittey, M., Bennita Chiwero, N., \& Habib, A. (2020). Updates on Wuhan 2019 novel coronavirus epidemic. Journal of Medical Virology, 92(4), 403-407. https://doi.org/10.1002/jmv.25695

Liu, J., Liao, X., Qian, S., Yuan, J., Wang, F., Liu, Y., Wang, Z., Wang, F. S., Liu, L., \& Zhang, Z. (2020). Community transmission of severe acute respiratory syndrome Coronavirus 2, Shenzhen, China, 2020. Emerging Infectious Diseases, 26(6), 1320-1323. https://doi.org/10.3201/eid2606.200239

Lu, H., Stratton, C. W., \& Tang, Y. W. (2020). Outbreak of pneumonia of unknown etiology in Wuhan, China: The mystery and the miracle. In Journal of Medical Virology (Vol. 92, Issue 4, pp. 401-402). John Wiley and Sons Inc. https://doi.org/10.1002/jmv.25678

Mikhael, E. M., \& Al-Jumaili, A. A. (2020). Can developing countries face novel coronavirus outbreak alone? The Iraqi situation. Public Health in Practice, 1, 100004. https://doi.org/10.1016/j.puhip.2020.100004

Mona, N. (2020). Konsep Isolasi dalam jaringan Sosial untuk Meminimalisir Efek Contagious (Kasus Penyebaran Corona di Indonesia). Jurnal Sosial Humaniora Terapan, 2(2). https://doi.org/10.7454/JSHT.V2I2.86

Nasution, M. S., \& Fadillah, N. (2019). Deteksi Kematangan Berdasarkan Warna Buah dengan Menggunakan Metode YCbCr. InfoTekJar:Jurnal Nasional Informatika Dan Teknologi Jaringan, 3(2), 147-150.

Notoatmodjo, S. (2003). Pendidikan dan Perilaku Kesehatan. Rineka Cipta.

Republik Indonesia. (2003). Undang-Undang RI Nomor 20, Tahun 2003, tentang 
Sistem Pendidikan Nasional.

Shah, A. U. M., Safri, S. N. A., Thevadas, R., Noordin, N. K., Rahman, A. A., Sekawi, Z., Ideris, A., \& Sultan, M. T. H. (2020). COVID-19 outbreak in Malaysia: Actions taken by the Malaysian government. International Journal of Infectious Diseases, 97, 108-116. https://doi.org/10.1016/j.ijid.2020.05.093

Shereen, M. A., Khan, S., Kazmi, A., Bashir, N., \& Siddique, R. (2020). COVID19 infection: Origin, transmission, and characteristics of human coronaviruses. Journal of Advanced Research, 24, 91-98. https://doi.org/10.1016/j.jare.2020.03.005

Sulistyo, I. A. (2017). Sistem Deteksi Panen Padi Berdasarkan Warna Daun Menggunakan Fuzzy C-Means. In Tugas Akhir Universitas Muhamadiyah Surakarta. Universitas Muhamadiyah Surakarta.

Suryahadi, A., Al Izzati, R., \& Suryadarma, D. (2020). The Impact of COVID-19 Outbreak on Poverty: An Estimation for Indonesia (Draft). SMERU Working Paper, April, 1-20. http://smeru.or.id/en/content/impact-covid-19-outbreakpoverty-estimation-indonesia

Susilawati, S., Falefi, R., \& Purwoko, A. (2020). Impact of COVID-19's Pandemic on the Economy of Indonesia. Budapest International Research and Critics Institute (BIRCI-Journal): Humanities and Social Sciences, 3(2), 1147-1156. https://doi.org/10.33258/birci.v3i2.954

WHO. (n.d.). Modes of transmission of virus causing COVID-19: implications for IPC precaution recommendations. Scientific Brief. Retrieved August 5, 2020, from https://www.who.int/news-room/commentaries/detail/modes-oftransmission-of-virus-causing-covid-19-implications-for-ipc-precautionrecommendations

WHO. (2015). Infection prevention and control of epidemic-and pandemic prone acute respiratory infections in health care. In WHO Guidelines. World Health Organization.

Yanti, B., Wahyudi, E., Wahiduddin, W., Novika, R. G. H., Arina, Y. M. D., Martani, N. S., \& Nawan, N. (2020). COMMUNITY KNOWLEDGE, ATTITUDES, AND BEHAVIOR TOWARDS SOCIAL DISTANCING POLICY AS PREVENTION TRANSMISSION OF COVID-19 IN INDONESIA. Jurnal Administrasi Kesehatan Indonesia, 8(2), 4. https://doi.org/10.20473/jaki.v8i2.2020.4-14 